\title{
RESEARCH OF CHEMICAL COMPOSITION OF VEGETABLE RAW MATERIALS FOR USE IN INNOVATIVE TECHNOLOGIES OF BEVERAGES FOR CHILD NUTRITION
}

\author{
Sobko Anna \\ PhD, Associate Professor \\ Department of Hotel-restaurant Business and Tourism \\ East European University of Economics and Management \\ Nechuya-Levitsky str., 16, Cherkasy, Ukraine, 18036 \\ ann.sobko@i.ua \\ Svidlo Karyna \\ Doctor of Technical Sciences, Professor, the Head of Department \\ Department of Innovative Food and Restaurant Technologies \\ Kharkov Trade and Economic Institute of Kiev National Trade and Economic University of Ukraine \\ O. Yarosha lane, 8, Kharkiv, Ukraine, 61045 \\ karinasvidlo@gmail.com \\ Horobets Victoria \\ Teacher \\ Cherkasy Commercial Technical School \\ Smelanskaja str., 84,Cherkasy, Ukraine, 18008 \\ vic.horobets@gmail.com
}

\begin{abstract}
The relevance of the study is due to the establishment of scientific data on the inferiority of child nutrition and the possibility of improving the diet through innovative technologies of beverages based on vegetable raw materials.

The data on the substantiation of the choice of vegetable raw materials for the production of child smoothies are given.

Their expediency, nutritional and energy value are characterized. Data on the chemical composition of the created beverages are given, which confirm the effectiveness of used raw materials.

Functional foods should meet $1050 \%$ of daily needs. When creating functional compositions, a key place is occupied by a set of predicted functional and technological characteristics and properties, compatibility and specificity of interaction with other components of recipe mixtures and finished products. Just this complex determines the feasibility of using functional compositions for culinary products.

Functional products are created on the principle of food combinatorics by reasonable quantitative selection of basic raw materials, ingredients, food supplements, the combination of which provides the formation of the desired organoleptic and physicochemical properties, as well as a given level of nutritional, biological and energy value.

The aim of the study: to establish the chemical composition of vegetable raw materials and the development of innovative technologies for child food beverages based on functional compositions, recipe mixtures and finished products.

Keywords: vegetable raw materials, sweet beverages, child nutrition, smoothie, preschool children, protein-vegetable mixture
\end{abstract}

DOI: $10.21303 / 2504-5695.2021 .001884$

\section{Introduction}

Experience in the development of technologies that ensure the rational use of raw materials has been accumulated in the scientific and practical activities of the production of beverages for child nutrition [1].

Drinks and desserts are gaining popularity among children. Smoothies are a cold dessert drink in the form of berries or fruits, crushed and mixed in a blender, (usually one type) with the addition of pieces of ice, juice or milk.

In recent decades, a fundamentally new direction of the drink has appeared drinksbreakfast (breakfast drinks or smoothies). Smoothies are a dense viscous product, which is both a drink and a quick breakfast with the addition of dairy and fruit parts, dietary fiber and vitamins, ie the 
chemical composition of the product is very close to the requirements of nutrition for children. The market of «healthy» drinks in Ukraine and the world as a whole is constantly growing, its segment of special purpose drinks is not fully formed. Along with sports and tonic drinks, the functional beverage segment is still being formed in the world.

High-quality, natural raw materials are used to make smoothies. In Switzerland, for example, popular smoothies contain $20 \%$ of skimmed sour milk and $52 \%$ of fruit juice (TM CoopBettyBossi); in the Netherlands, smoothies based on low-fat yogurt, low sugar and $60 \%$ of natural lime or peach juice (TM SisiFrutmania) are common, the UK prefers products with soy extract and high content of fruit pieces (TM TomSoya), with natural carrot juice (TM), Ireland produces drinks with more than $50 \%$ of fruit pieces in combination with low-fat yogurt (TM Tropicana Smoothies).

Wide involvement of local and non-traditional raw materials will increase the quality and biological value of child food. This gives grounds to claim that drinks for child nutrition have potentially favorable prospects for development due to the introduction of innovative technologies based on functional compositions, despite the negative impact of the external environment. The relevance of the study is due to the establishment of scientific data on the inferiority of child nutrition and the possibility of improving the diet.

The main problem of creating drinks for child food with a given set of quality properties is a complex process of ensuring the most complete balance and structure of products. The right choice of a raw material base plays an important role in solving this problem.

\section{Materials and methods}

The object of research is the smoothie technology based on model functional compositions (MFC).

The subject of research: almonds (GOST 16831-71), walnut (GOST 16832-71), sesame (TC U 01.1-24435116-002-2010), protein-vegetable mixture «Milkosoy-1», smoothies: «Carotelka», «Nut «,»Fig milk «,»Beta-charge «.

Preparation of test samples based on model functional compositions (MFC) was carried out in accordance with the traditional technology, control samples according to the classical recipe [2].

\section{Research results}

The lack of scientific research to meet the demand for functional foods for preschool children determines the relevance of the search for new types of raw materials with a high biological value.

Important issues of food development for preschool children are revealed in scientific works of Peresichny M.I. (2016), Peresichna S. M. (2014), Pyatnytska N. O. (2012), Nyankovsky S. L. (2018), Korzun V. N. (2020), Podrushnyak A. E. (2020), Kaprelyants L. V. (2021).

Berries and fruits are rich in various acids (caffeic, citric, tartaric and malic) and tannins [3]. They are a valuable raw material for the content of flavonoids, which is important for the child organism. Flavonoids are one of the most diverse and common groups of phenolic compounds.

Today, more than 8,000 flavonoids are known. They are widespread in the plant world and are characterized by an exceptional diversity of species [4].

Flavonoids can also be called natural plant dyes. However, they are contained only in plants, but in no case in the animal organism. Most flavonoids are contained in bilberries, blueberries, sea buckthorn, apricot [5].

Consider the influence of vegetable raw materials on the basic functions of the preschool children's organism.

Pumpkin contains large amounts of vitamin $\mathrm{K}$, which is present in almost none fruit and vegetable. Vitamin K deficiency leads to nosebleeds and bleeding gums [6].

Pumpkin juice also has the ability to remove radionuclides from the organism. This ability is achieved due to the presence of water-soluble dietary fiber, which exponentially enhances the work of the intestine, its motor function. Pumpkin juice is generally suitable for cleansing the organism. It cleanses blood vessels from excess cholesterol, normalizes the water-salt balance [7].

When designing model functional compositions of smothies, it is taken into account, that calcium reduces magnesium absorption, vitamin $\mathrm{C}$ restores oxidized vitamin $\mathrm{E}$, and zinc reduces 
calcium absorption, B vitamins are incompatible with vitamin PP, calcium and zinc reduce iron absorption, calcium and iron reduce zinc absorption in the intestine, zinc reduces the absorption of copper, copper increases the benefits of iron many times $[8,9]$. The recommended ratio of calcium: phosphorus: magnesium for preschool children is 1:1:6.7.

Lack of nuts and seeds in the diet of preschool children has been recognized as one of the systematic errors in nutrition, according to a study, published in the journal The Lancet in 2019. Why should nuts be included in the daily diet of children of different ages?

Nuts and seeds are useful, first of all, by: high protein content (1020\% depending on the type of nuts or seeds), full protein composition, high content of unsaturated fatty acids, including long-chain polyunsaturated omega-3 and omega- 6 fatty acids. Nuts contain tocopherols, B vitamins, fiber (3.510\% depending on the type of nuts or seeds), trace elements (iron, selenium, zinc, calcium, magnesium, potassium)

We'll conduct a comparative analysis of the chemical composition of cow milk and milk from nuts and seeds (Table 1).

Table 1

Analysis of the chemical composition of nuts, $100 \mathrm{~g}$

\begin{tabular}{|c|c|c|c|c|c|c|c|c|}
\hline \multicolumn{2}{|c|}{ Element name } & Cow milk & Almond & $\begin{array}{c}\text { Difference, } \\
\%\end{array}$ & Walnut & $\begin{array}{c}\text { Difference, } \\
\%\end{array}$ & Sesame & Difference, $\%$ \\
\hline \multicolumn{2}{|c|}{ Proteins, $g$} & 2.8 & 18.6 & 664.2 & 16.2 & 578.5 & 19.4 & 692.8 \\
\hline \multicolumn{2}{|c|}{ Fats, g } & 3.2 & 57.7 & 1803.1 & 60.8 & 1900 & 48.7 & 1521.8 \\
\hline \multicolumn{2}{|c|}{ Saturated fatty acids, $g$} & 2 & 5 & 250 & 5.5 & 275 & 6.6 & 330 \\
\hline \multicolumn{2}{|c|}{ Polyunsaturated fatty acids } & 1.2 & 7.2 & 600 & 30.4 & 2533.3 & 44 & 3666.6 \\
\hline \multicolumn{2}{|c|}{ Monounsaturated fatty acids, $g$} & 18 & 31 & 172.2 & 18.2 & 101.1 & 48 & 266.6 \\
\hline \multicolumn{2}{|c|}{ Carbohydrates, g } & 4.7 & 13 & 276.5 & 11.1 & 236.1 & 26.04 & 554 \\
\hline & A. $\mathrm{mcg}$ & 0.02 & 3 & 15000 & 8 & 40000 & & \\
\hline \multirow{9}{*}{ Vitamins, mg } & B) & 0.04 & 0.3 & 625 & 0.4 & 975 & 1.3 & 3125 \\
\hline & $\mathrm{E}$ & & 24.6 & & 2.6 & & 2.3 & \\
\hline & $\mathrm{B}^{r}$ & 0.2 & 0.7 & 433.3 & 0.1 & 80 & 0.3 & 166,6 \\
\hline & $\mathrm{B}^{7}$ & 0.05 & 0.3 & 600 & 0.8 & 1600 & 0.4 & 720 \\
\hline & $\mathrm{B}^{0}$ & 0.4 & 0.04 & 10 & 0.8 & 200 & & \\
\hline & $\mathrm{B}^{9} . \mathrm{mcg}$ & 5 & 40 & 800 & 77 & 1540 & 97 & 1940 \\
\hline & Beta-carotene & 1 & 0.02 & 2 & 0.05 & 5 & & \\
\hline & C. $\mathrm{mcg}$ & 1.3 & 1.5 & 115.3 & 5.8 & 446.1 & & \\
\hline & PP & 0.1 & 4 & 4000 & 4.8 & 4800 & 4 & 4000 \\
\hline \multirow{16}{*}{$\begin{array}{l}\text { Mineral sub- } \\
\text { stances }\end{array}$} & $B \leqslant$ & & 52.1 & & & & & \\
\hline & Calcium & 120 & 273 & 227.5 & 89 & 74.1 & 1474 & 1228.3 \\
\hline & Magnesium & 14 & 234 & 1671.4 & 120 & 857.1 & 540 & 3857.1 \\
\hline & Sodium & 50 & 10 & 20 & 7 & 14 & 39 & 78 \\
\hline & Potassium & 146 & 748 & 512.3 & 474 & 324.6 & 497 & 340,4 \\
\hline & Phosphorus & 90 & 473 & 525.5 & 332 & 368.8 & 720 & 800 \\
\hline & Chlorine & 110 & 39 & 35.4 & 25 & 22.7 & & \\
\hline & Manganese & 0.006 & 1.92 & 32000 & 1.9 & 31666 & 2.46 & 41000 \\
\hline & Iodine, mcg & 9 & 2 & 22.2 & 3.1 & 34.4 & & \\
\hline & Iron & 0.06 & 4.2 & 7000 & 2 & 3333.3 & 61 & 101667 \\
\hline & Sulfur & 29 & 175 & 603.4 & 100 & 344.8 & & \\
\hline & Selenium & & 2.5 & & 4.9 & & & \\
\hline & Zinc & 0.4 & 2.1 & 530 & 2.5 & 630 & 7.2 & 1790 \\
\hline & Copper, mcg & 12 & 142 & 1183.3 & 527 & 4391.6 & 4.08 & 34 \\
\hline & Fluorine, mcg & 20 & 91 & 455 & 685 & 3425 & & \\
\hline & Silicon & & 50 & & 60 & & 199 & \\
\hline \multicolumn{2}{|c|}{ Energetic value } & 58 & 649 & 1118.9 & 630 & 1086.2 & 605 & 1043.1 \\
\hline
\end{tabular}


The comparative analysis of the raw materials for the smoothie showed that protein in almonds and walnuts is 5-6 times more than in cow milk. Fat in almonds, walnuts is 1519 times more than in the control sample, in sesame - 15 times. Carbohydrates in almonds and walnuts are 2 times more, in sesame 5 times. Vitamin A in almonds is 15 times more, in walnuts 40 times. Vitamin B9 in nuts is 19 times more, and vitamin B1 in sesame 31 times. Vitamin $\mathrm{C}$ in almonds and walnuts is 24 times more. Calcium in almonds is 2 times more, in walnuts by $89 \%$, in sesame 12 times. Magnesium in almonds is 16 times more, in walnuts 8 times, in sesame 38. Phosphorus in almonds and walnuts is 35 times more, in sesame 8 times.

Thus, nut milk is not biologically inferior to cow milk and significantly exceeds it by the content of minerals and vitamins. Comparing the chemical composition of almonds and walnuts, it was found, that almonds contain more vitamins and trace elements than walnuts, but as far as almonds are more valuable raw material, walnuts are better to use for smoothies due to economic benefits.

Given the above, we consider it appropriate to use sesame seeds, walnuts and berries to develop innovative smoothie technologies that increase the resistance and adaptability of the child organism, due to the content of functional ingredients of natural origin.

Studies of the chemical composition of the dietary supplement «MILKOSOY-1» for the preparation of child milkshakes have shown that this product is non-toxic, low-energy, non-addictive, successfully used as a milk substitute for human intolerance to dairy products. Milkosoy 1 has been clinically tested and recommended for use as a substitute for dairy products [10].

Today there is a wide range of soy protein supplements, which differ in composition, properties, purpose and price, which creates a problem of choice in a variety of proposals. When choosing soy protein supplements for use in beverages for functional purposes, along with functional and technological properties, such as water and fat-binding capacity, emulsifying properties, etc., one focused on their high nutritional value and safety, affordability, ease of use, while giving preference to domestic products. The above requirements are met by soybean products "Super", "Milkosoy", "Tonus" under the ECO trademark.

The Ministry of Health of Ukraine classified ECO products from awakened grain as special foods that have therapeutic and prophylactic properties and can be used in the following areas: for feeding children in organized educational and health children's groups; for nutrition of patients in treatment and treatment-and-prophylactic institutions; at medical and preventive nutrition of persons, working in harmful conditions, including at NPPs, as well as living in areas, contaminated with radionuclides; in the therapeutic and prophylactic nutrition of persons with pathologies of the digestive organs and thyroid gland; to improve the quality of nutrition of the elderly, pregnant women and nursing mothers.

The composition of the protein components of «MILKOSOY-1» includes all essential amino acids, it has a balanced mineral composition, presented in Table. 2.

The studies on the content of macro- and microelements of the dietary supplement «MILKOSOY-1» are presented below (Fig. 1). The results of the study of the chemical composition are shown in Table 3.

After performing the experiment to determine the content of macro and microelements in the dietary supplement «MILKOSOY-1», it was found, that the content of minerals is almost the same as in milk.

The studies on the dependence of the dietary supplement «MILKOSOY-1» on the specified proportions and temperatures were also performed. The research results are given below in Table. 4.

After conducting the experiments to determine the dependence of the dietary supplement «MILKOSOY-1» on the specified proportions and temperatures, it was found, that at a ratio of 1:2 and at a temperature of $55^{\circ} \mathrm{C}$, this product dissolves best in boiled water, the consistency is homogeneous and almost without lumps and the presence of sediment. 
Table 2

Nutritional and energy value of "MILKOSOY-1" (g/100 g)

Parameters, (g, mg)

Dry substances

Proteins, $g$

Including essential amino acids:

valine
isoleucine
leucine
lysine
methionine
threonine
tryptophan
phenylalanine
Fats, g
polyunsaturated fatty acids
es, g, including dietary fiber

Carbohydrates, g, including dietary fiber

Amount

II

95.0

25.3

10.3

1.46

1.43

2.26

1.85

0.41

1.36

0.38

1.17

10.2

5.7

51.2

3.6

5.4

770

950

8.2

4.8

190

0.041

398

Table 3

Concentration of macro- and micronutrients in the sample ( $\mathrm{mcg} / \mathrm{g}$ )

\begin{tabular}{ccc}
\hline Macro- and microelements & Concentration & Average statistical error \\
\hline $\mathrm{K}$ & $6542.9270+_{-}$ & 198.74000 \\
$\mathrm{Ca}$ & $2537.2370+_{-}$ & 86.09200 \\
$\mathrm{Cr}$ & $1.3497+_{-}$ & 0.52273 \\
$\mathrm{Mn}$ & $2.7534+_{-}$ & 0.72171 \\
$\mathrm{Fe}$ & $34.2822+_{-}$ & 2.34470 \\
$\mathrm{Ni}$ & $1.9957+_{-}$ & 0.45128 \\
$\mathrm{Zn}$ & $16.1357+_{-}$ & 1.45820 \\
$\mathrm{Br}$ & $10.5392+_{-}$ & 0.83494 \\
$\mathrm{Rb}$ & $5.3791+_{-}$ & 0.50677 \\
$\mathrm{Sr}$ & $13.1857+_{-}$ & 0.80528 \\
$\mathrm{~S}$ & $3345.966+_{+}$ & 567.38000 \\
$\mathrm{Cu}$ & $2.2664+_{-}$ & 0.54612 \\
$\mathrm{Zr}$ & $0.6223+_{-}$ & 0.16502
\end{tabular}




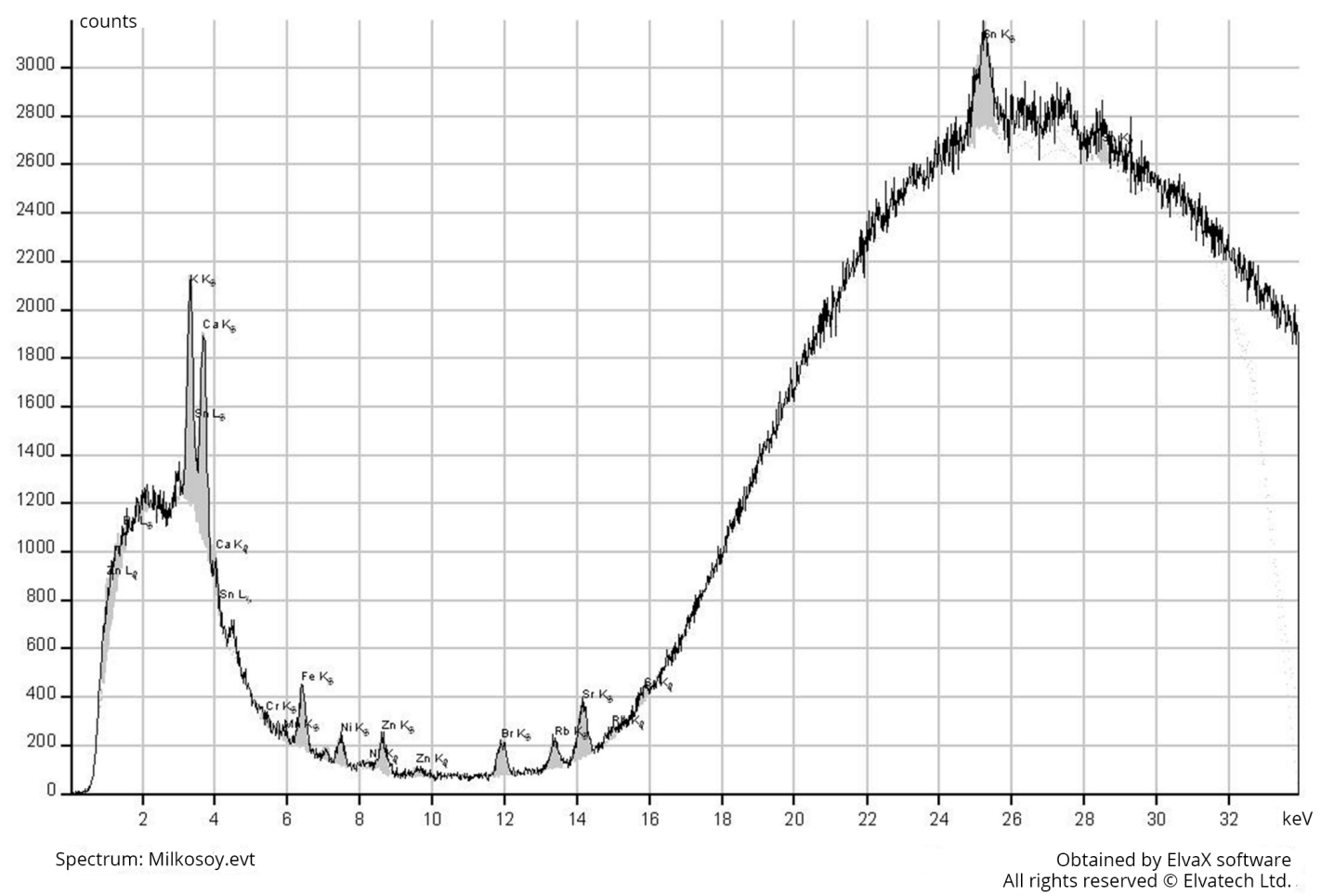

Fig. 1. Content of macro- and microelements of the dietary supplement «MILKOSOY-1»

Table 4

Determination of the dependence of the state of the dietary supplement "MILKOSOY-1" on the specified proportions and temperatures

\begin{tabular}{|c|c|}
\hline & Proportions \\
\hline temperature & $1: 1$ \\
\hline $40^{\circ} \mathrm{C}$ & $\begin{array}{l}\text { Heterogeneous, thick consistency, } \\
\text { a large number of lumps after } \\
\text { thorough mixing. The presence of } \\
\text { sediment. }\end{array}$ \\
\hline $45^{\circ} \mathrm{C}$ & $\begin{array}{l}\text { Heterogeneous, thick consistency, } \\
\text { a large number of lumps after } \\
\text { thorough mixing. The presence of } \\
\text { sediment. }\end{array}$ \\
\hline $50^{\circ} \mathrm{C}$ & $\begin{array}{l}\text { Heterogeneous, thick consistency, } \\
\text { a large number of lumps after } \\
\text { thorough mixing. The presence of } \\
\text { sediment. }\end{array}$ \\
\hline $55^{\circ} \mathrm{C}$ & $\begin{array}{l}\text { Heterogeneous, thick consistency, } \\
\text { a large number of lumps after } \\
\text { thorough mixing. The presence } \\
\text { of sediment. }\end{array}$ \\
\hline $60^{\circ} \mathrm{C}$ & $\begin{array}{l}\text { Heterogeneous, thick consistency, } \\
\text { a large number of lumps after } \\
\text { thorough mixing. The presence of } \\
\text { sediment. }\end{array}$ \\
\hline
\end{tabular}

Thus, given the high technological properties and positive effects of soy products on all types of metabolism protein, fat, carbohydrates, on the mechanisms of regulation of life support 
of the mucous membranes of the gastrointestinal tract, ECO soy products can be considered an important component in functional food technology.

New technologies of preparation of smoothies for children of preschool age (46 years) on the basis of the dietary supplement "MILKOSOY" are developed. Below are technological schemes, technologies and functional compositions of beverages.

The technology of the «Beta-charge» smoothie includes bringing water to a boil, cooling it to a temperature of $55^{\circ} \mathrm{C}$, adding the dietary supplement «MILKOSOY», thorough mixing to a uniform consistency. Pumpkin is washed, cut, cleaned of seeds and pulp, cut into pieces, baked, ground in a blender to a puree.

Sea buckthorn is washed, crushed, seeds and skins are removed. The puree is brought to a boil and cooled. Berry and vegetable puree, protein-vegetable mixture is whipped to a homogeneous consistency with honey (Fig. 2).

The technology of the «Fig milk» smoothie includes bringing water to a boil, cooling it to a temperature of $55^{\circ} \mathrm{C}$, adding the dietary supplement «MILKOSOY - 1», thorough mixing to a homogeneous consistency. Figs are thoroughly washed, rubbed with sugar, poured with boiling water and infused for 4 hours, filtered. The finished mixtures are mixed to a homogeneous consistency (Fig. 3).

The "Carotelka" smoothie technology includes the preparation of a protein-vegetable mixture and carrot puree with cardamom and honey. The finished mixture is whipped to a homogeneous consistency (Fig.4).

To prepare the «Nut» smoothie, dried apricots are thoroughly washed and chopped. Walnut kernels are cleaned and passed through a meat grinder. Pour dried apricots with nuts with boiling water and leave to infuse for 1015 minutes, then strain. The finished mixture is whipped to a homogeneous consistency (Fig.5).

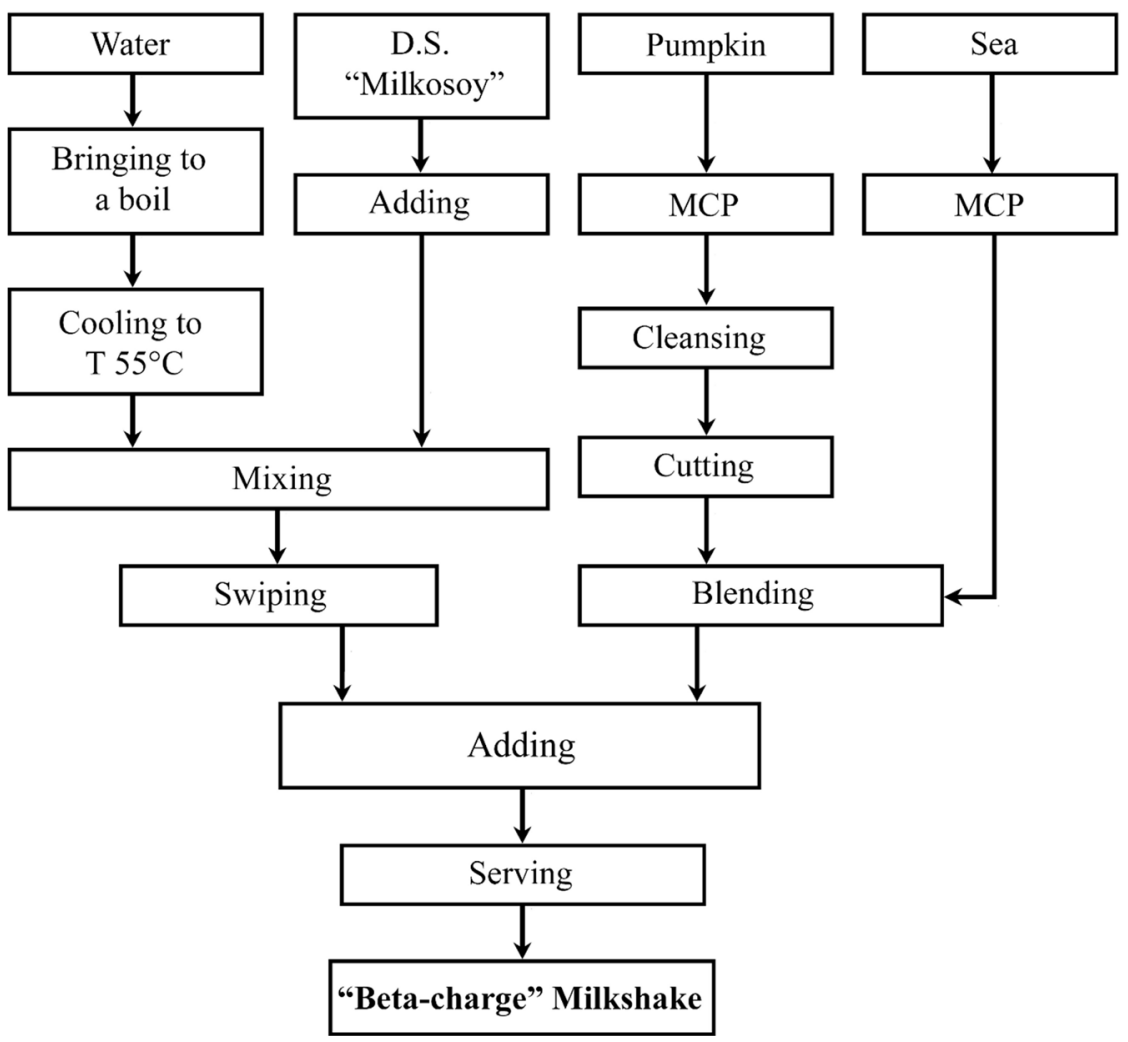

Fig. 2. Technological scheme of "Beta-charge" milkshake 


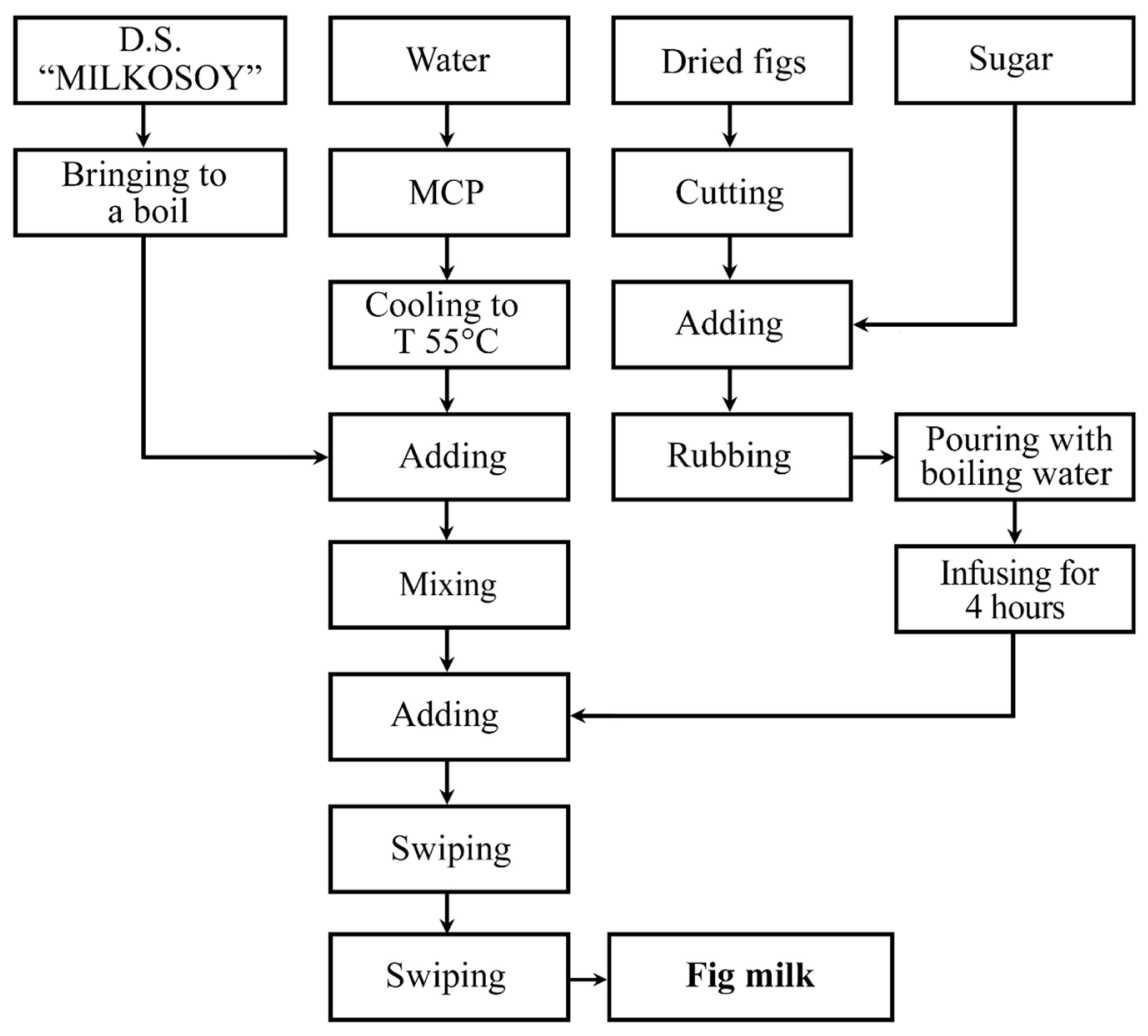

Fig. 3 Technological scheme of "FigMilk" milkshake

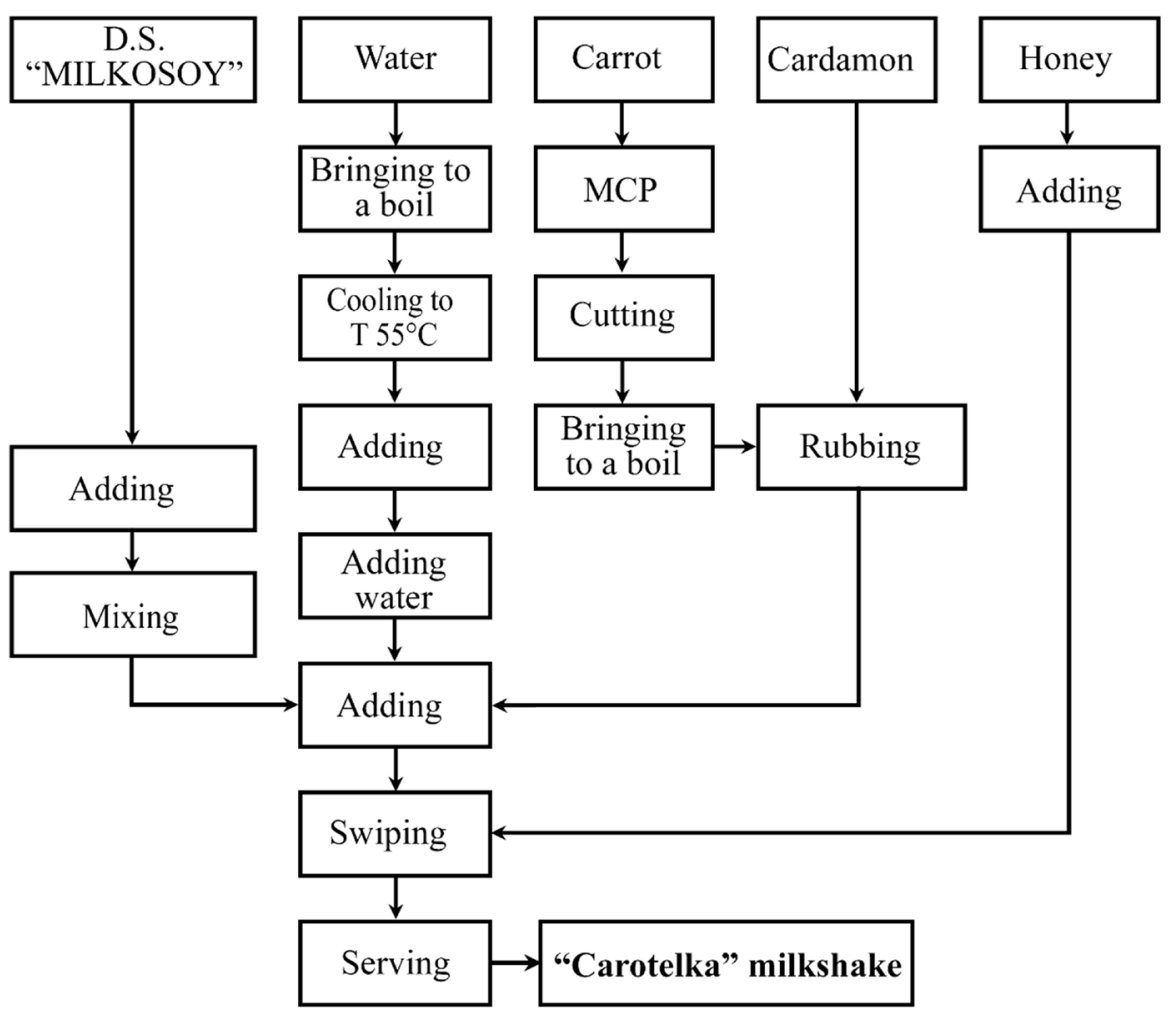

Fig. 4. Technological scheme of "Carotelka" milkshake 


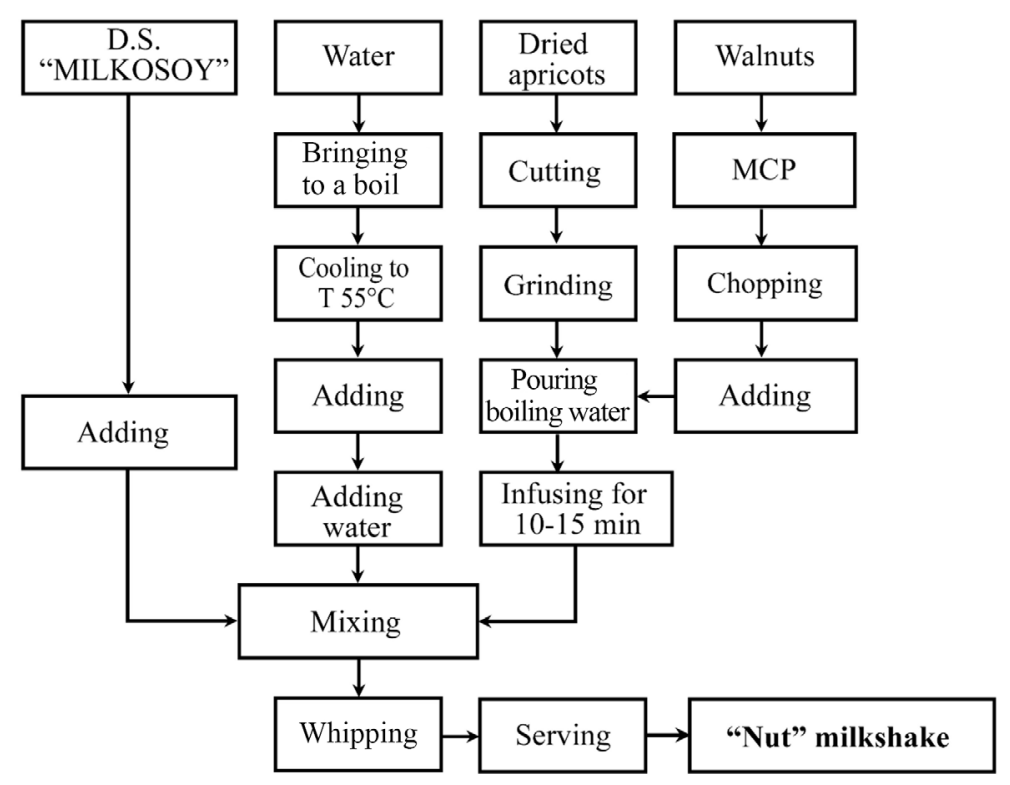

Fig. 5. Technological scheme of "Nut"milkshake

The developed technologies of the smoothies reflect the interaction between vitamins and trace elements (Table 5).

Table 5

Design of beverage technologies for child nutrition

\begin{tabular}{|c|c|c|c|c|c|}
\hline Names & Synergism of nutrients & $\begin{array}{l}\text { Daily need in } \\
\text { nutrients }\end{array}$ & $1050 \%$ & $\begin{array}{l}\text { Composition of ingre- } \\
\text { dients for } 200 \mathrm{~g} \text { of the } \\
\text { output (1portion) }\end{array}$ & $\begin{array}{c}\text { Content of microele- } \\
\text { ments }\end{array}$ \\
\hline 1 & 2 & 3 & 4 & 5 & 6 \\
\hline (control) & - & $\begin{array}{c}\text { A-500 mcg } \\
\text { Potassium - } 150 \mathrm{mg} \\
\text { C-55 mg } \\
\text { Ca }-1000 \mathrm{mg}\end{array}$ & $\begin{array}{c}50 \ldots 250 \\
15 \ldots .75 \\
5.5 \ldots 27.5 \\
100 \ldots 500\end{array}$ & $\begin{array}{l}\text { Sea buckthorn } 85 \mathrm{~g} \\
\text { water } 100 \mathrm{~g} \\
\text { lemon } 5 \mathrm{~g} \\
\text { cinnamon } 5 \mathrm{~g} \\
\text { mint } 5 \Gamma\end{array}$ & $\begin{array}{c}\mathrm{A}-0.18 \mathrm{mg} \\
\text { Potassium }-6.9 \mathrm{mg} \\
\mathrm{C}-0.19 \mathrm{mg} \\
\mathrm{Ca}-12.15 \mathrm{mg}\end{array}$ \\
\hline $\begin{array}{l}\text { "Beta- } \\
\text { charge" }\end{array}$ & $\begin{array}{l}\mathrm{Ca}_{+} \mathrm{Mg}+\mathrm{C}+\mathrm{F}=\text { assimilation } \\
\text { of microelements for the de- } \\
\text { velopment of teeth and bones }\end{array}$ & $\begin{array}{l}\mathrm{Ca}-1000 \mathrm{mg} \\
\mathrm{Mg}-15 \mathrm{mg} \\
\mathrm{C}-55 \mathrm{mg} \\
\mathrm{F}-1 \mathrm{mg}\end{array}$ & $\begin{array}{c}100 \ldots 500 \\
1,5 \ldots 7,5 \\
5.5 \ldots 27.5 \\
0.1 \ldots 0.5\end{array}$ & $\begin{array}{c}\text { "Milkosoy-1"100 } \mathrm{ml} \text { or } \\
\text { nut milk } \\
\text { pumpkin } 50 \mathrm{~g} \\
\text { sea buckthorn } 50 \mathrm{~g} \\
\text { flower honey } 5 \mathrm{~g}\end{array}$ & $\begin{array}{c}\mathrm{Ca}-1474 \mathrm{mg} \\
\mathrm{Mg}-21 \mathrm{mg} \\
\text { Potassium }-6.9 \\
\mathrm{C}-30 \mathrm{mg} \\
\mathrm{F}-0.15 \mathrm{mcg}\end{array}$ \\
\hline $\begin{array}{l}\text { "Fig } \\
\text { milk" }\end{array}$ & $\begin{array}{l}\mathrm{C}+\mathrm{Zn}+\mathrm{A}=\text { assimilation } \\
\text { of microelements for the } \\
\text { development of vision }\end{array}$ & $\begin{array}{c}\text { E-10 mg } \\
\text { Potassium - } 150 \\
\text { mg } \\
\text { B^. - } 9 \mathrm{mcg} \\
\text { C-55 mg } \\
\text { Zn-6 mg }\end{array}$ & $\begin{array}{c}1 \ldots 5 \\
15 \ldots 75 \\
8 \ldots 40 \\
5,5 \ldots 27.5 \\
0.6 \ldots 3\end{array}$ & $\begin{array}{l}\text { "Milkosoy }-1 " \\
100 \mathrm{ml} \\
\text { Dried figs }-35 \mathrm{~g} \\
\text { Flower honey } 5 \mathrm{~g}\end{array}$ & $\begin{array}{c}\text { E- 22.14mg } \\
\text { Potassium }-121.8 \mathrm{mg} \\
\text { B9 - } 7 \mathrm{mg} \\
\mathrm{C}-35 \mathrm{mg} \\
\mathrm{Zn}-4.7 \mathrm{mcg}\end{array}$ \\
\hline $\begin{array}{l}\text { "Carotel- } \\
\text { ka” }\end{array}$ & $\begin{array}{c}\mathrm{B}+\varepsilon \mathrm{B}+9 \mathrm{I}+\mathrm{A}=\text { assimilation } \\
\text { of microelements for the } \\
\text { development of digestive } \\
\text { organs, } \\
\text { metabolism }\end{array}$ & $\begin{array}{l}\text { B4-100 mg } \\
\text { B9-80 mcg } \\
\mathrm{I}-0.09 \mathrm{mg} \\
\mathrm{A}-500 \mathrm{mcg}\end{array}$ & $\begin{array}{c}10 \ldots 50 \\
8 \ldots 40 \\
0,009 \ldots \\
0,045 \\
50 \ldots 250\end{array}$ & $\begin{array}{c}\text { "Milkosoy }-1 " \\
100 \mathrm{ml} \\
\text { Carrot }-80 \mathrm{~g} \\
\text { Cardamon }-20 \mathrm{~g}\end{array}$ & $\begin{array}{l}\text { B } 4-5.8 \mathrm{mg} \\
\text { B9-7.6mcg } \\
\mathrm{A}-6.6 \mathrm{mcg}\end{array}$ \\
\hline "Nut" & $\begin{array}{c}\mathrm{B}+7 \mathrm{~B}+9 \mathrm{I}=\text { assimilation } \\
\text { of microelements for the } \\
\text { development of digestive } \\
\text { organs, } \\
\text { metabolism }\end{array}$ & $\begin{array}{l}\text { B6 -100 mg } \\
\text { B9-80 mcg } \\
\text { I-0.09 mg }\end{array}$ & - & $\begin{array}{c}\text { "Milkosoy }-1 " \\
100 \mathrm{ml} \\
\text { Walnuts }-80 \mathrm{~g} \\
\text { Dried apricots }-20 \mathrm{~g}\end{array}$ & $\begin{array}{l}\text { B6 - 5.8mg } \\
\text { B9-7.6mcg } \\
\quad \text { I- } 3.1 \mathrm{mg}\end{array}$ \\
\hline
\end{tabular}


Thus, the chemical composition of the vegetable raw materials was studied and innovative technologies of the child nutrition smoothies were developed.

\section{Conxlusions}

The studies of the chemical composition of the protein-vegetable mixture «MILKOSOY-1» have found that this product is non-toxic, low-energy, non-addictive, successfully used as a substitute for milk in case of human intolerance to dairy products. The protein components of «MILKOSOY-1» include all essential amino acids, it has the balanced mineral composition.

The ratio of the protein-vegetable mixture to water (1:2) and the temperature of the best dissolution in boiled water $55^{\circ} \mathrm{C}$, which provides a uniform consistency, have been established.

New technologies of preparation of drinks for child nutrition on the basis of the dietary supplement «MILKOSOY-1» have been developed. Technological schemes of beverage production are given.

According to the results of the research, the improved technology of beverage production based on functional compositions has been proposed.

The rational number of constituent compositions has been proved, as well as their influence on functional-technological properties, technological parameters and modes of advanced production.

\section{References}

[1] Cherevko, O. I., Peresichnyi, M. I., Peresichna, S. M. et. al.; Cherevko, O. I., Peresichnyi, M. I. (Eds.) (2017). Innovatsiini tekhnolohii kharchovoi produktsii funktsionalnoho pryznachennia. Ch. 1. Kharkiv: KhDUKhT, 962. Available at: https://elib. hduht.edu.ua/handle/123456789/1897?locale=en

[2] Mazaraki, A. A., Peresichnyi, M. I. et. al.; Peresichnyi, M. I. (Ed.) (2013). Zbirnyk retseptur kulinarnoi produktsii i napoiv z vykorystanniam diietychnykh dobavok. Kyiv: Kyiv. nats. torh.-ekon. un-t, 787.

[3] Yevlash, V. V., Priss, O. P., Serdiuk, M. Ye., Pavlotska, L. F., Skurikhina, L. A., Dudenko, N. V., Sukharenko, O. I. (2019). Biokhimiia plodiv ta ovochiv. Melitopol, 205. Available at: http://elar.tsatu.edu.ua/bitstream/123456789/9730/1/1.pdf

[4] Flavonoidy. Available at: https:/www.pharmencyclopedia.com.ua/article/408/flavonoidi

[5] Oblipykha ta kalyna: korysni vlastyvosti (2021). Available at: https://www.ukrinform.ua/rubric-yakisne-zhyttia/3135307-oblipiha-ta-kalina-korisni-vlastivosti-infografika.html

[6] Horobets, A. O. (2019). Vitamins and microelements as specific regulators of physiological and metabolic processes in the body of children and adolescents. Ukrainian Journal of Perinatology and Pediatrics, 4 (80), 75-92. doi: http://doi.org/10.15574/ pp.2019.80.75

[7] Vasko, L. M., Pocherniaieva, V. F., Bashtan, V. P. (2018). Zasoby zakhystuorhanizmu vid dii ionizuiuchoho vyprominennia. Poltava, 130. Available at: http://elib.umsa.edu.ua/jspui/bitstream/umsa/11686/3/Vasko_Mens_of_Protecting.pdf

[8] Shcho varto znaty pro mineralni dobavky (2019). Available at: https://moz.gov.ua/article/health/scho-varto-znati-pro-mineralni-dobavki

[9] Zeratsky, K. (2020). When should I take calcium supplements? Does the timing matter? Available at: https://mayocl.in/2EVCLF1

[10] Suprun, U. (2019). Pro koryst horikhiv ta yak yikh pravylno vzhyvaty. Available at: https://suprun.doctor/zdorovya/pro-koristgorixiv-ta-yak-yix-pravilno-vzhivati.html?=page1434

[11] Peresichnyi, M., Neilenko, S. (2009). Tekhnolohiia molochnykh i ovochevykh napoiv radiozakhysnoi dii. Tovary i rynky, 2 , 83-89. Available at: http://tr.knute.edu.ua/files/2009/08/13.pdf

[12] Gladkyi, F., Tymchenko, V., Nekrasov, P., Fediakina, Z., Kunitsa, E., Molchenko, S. (2018). Sensory analysis of food products. Kharkiv: PC TECHNOLOGY CENTER, 132. doi: http://doi.org/10.15587/978-617-7319-16-9

How to cite. Sobko, A., Svidlo, K., Horobets, V. (2021). Research of chemical composition of vegetable raw materials for use in innovative technologies of beverages for child nutrition. EUREKA: Life Sciences, 3, 53-62. doi: https://doi.org/10.21303/2504-5695.2021.001884 